\title{
11 Ronald Mar and the Trope of Life
}

\author{
The Translation of Western Modernist Poetry in Hong Kong
}

Chris Song

\begin{abstract}
This essay examines the Chinese-language debut of Western surrealist poetry in Hong Kong and its effect on the local poetry scene through the work of Ronald Mar 馬朗, from the early years of the Cold War era onward. It traces the trope of poetry being "true to life" - as resistance to the surrealist influence - through evolving notions and experiences of Hong Kong identity over time, up to the present day in the post-handover era.
\end{abstract}

Keywords: Chinese poetry, translation, Ronald Mar, Hong Kong, modernism, surrealism

Twenty years since the handover of sovereignty from the British Crown to the People's Republic of China, Hong Kong society has known increasingly severe conflicts with China, fueled by animosity toward the mainland among the local population. Growing up in such a politically intense environment, Hong Kong youths feel that political and economic systems have conspired to leave them a hopeless future. As their demand for universal suffrage in the election of the Chief Executive of the Hong Kong Special Administrative Region government was denied in September 2014, their anxiety finally broke into realization as the Umbrella Movement. Apart from responding through poetry to this large democratic movement, some young local poets perceived a need to redefine the "localness" of Hong Kong poetry. Though without much theoretical depth, their quest is quite clear: they believe that the localness of their poetic language lies, paradoxically, in the distance from external reality - a symbolic denial of the Umbrella Movement's failed demands for universal suffrage, or any further realistic democratization, in

Van Crevel, Maghiel and Lucas Klein (eds.), Chinese Poetry and Translation: Rights and Wrongs. Amsterdam: Amsterdam University Press, 2019 DOI: $10.5117 / 9789462989948$ CH11 
fact - and that their poetry must express such distance through abstract surrealistic imagery.

In 2015, this emerging trend met with a sharp attack by senior poet Chung Kwok-keung 鍾國強. Chung criticizes that their poetry

appears to mean something, but as we read it we find it empty and superficial, elusive and eventually unsolvable ... Instead of enriching the poem and making it more readable, the many ambiguities produced in the process of reading become so many layers of obstacles. Meaning is lost in the labyrinth of language. Emotion in the poem, if any, is abstruse. $(2015,10)^{1}$

Following this critique is Chung's summary introduction to the poetry from Selected Poems of Ten Poets (十人詩選) (Qian 1998). Curated by the prominent Hong Kong poet Leung Ping-kwan 梁秉鈞 (1949-2013), this anthology has achieved canonical status in the history of Hong Kong literature; it collects ten Hong Kong Chinese-language poets whose works have been labeled as "true to life" (生活化). As one of the current leaders of the true-to-life school, Chung wrote this critique out of his dissatisfaction with what he sees as the young surrealist poets' weakness, namely, their dissociating poetry from life. Chung's article was in turn savaged by the young surrealists, who justify their poetic practice on the models of postmodern Taiwanese poets Hsia Yü 夏宇, Hung Hung 鴻鴻, and Luo Chi-cheng 羅智成. They further propose to incorporate their surrealist poetry into the true-to-life tradition for its greater enrichment (Mu 2015; Huang 2015), treating "life" (生活) almost as a purely theoretical concept. In other words, life is theorized away.

This recent dispute over the trope of life in the Hong Kong poetry scene continues a long-lasting resistance against the influence of surrealism since its introduction in the 1950s through translations by Ronald Mar 馬 朗 (1933?), who was born in the United States, came to China at the end of the Second World War, and moved on to Hong Kong after the Communist takeover of the mainland. In this paper, I will explicate the dispute over the trope of life in the ideological environment of Hong Kong in the 1950s and analyze Mar's translation of Western modernist poetry, especially surrealist poetry. By pointing out the inherent contradiction between the real and the surreal in his translations and other writings, I argue that the translation of Western surrealist poetry failed to exert far-reaching influence on the writing of Hong Kong poetry. The reason is that, while inheriting 
poetics borrowed from Western modernism through Mar's translations, the generation of poets who rose to Hong Kong's literary scene in the $1970 \mathrm{~s}$ recanted surrealism out of a need to pursue a cultural identity through the writing of local life. Tracing the transformation of the trope of life since the $195 \mathrm{os}$, this paper offers a reinterpretation of the present trend of surrealism in Hong Kong poetry today.

\section{The trope of life and Romantic poetry}

After the founding of the People's Republic of China in 1949, Hong Kong's Chinese literary landscape was caught in an ideological tug-of-war between two political forces, resulting from a two-way migration of Chinese intellectuals with opposing political beliefs. Many leftist writers who had taken refuge in Hong Kong during the Chinese civil war moved back to mainland China, where they wanted to participate in constructing the culture of New China. They continued to create works that shared the general characteristics of mainland-leftist poetry, usually slogan-laden odes that evoked a nationalistic mood on the theme of founding a new China, everyday people's hard work in everyday life, injustice under capitalism and the forthcoming proletarian revolution in Third World countries, and so on. These works were still published in magazines and newspapers in Hong Kong, especially those controlled by mainland political forces; but without immediate life experiences in the British colony, most "northbound" (北 返) leftist poets produced works that demonstrated detachment from local life, that is, disengagement from the struggle for survival in postwar Hong Kong. At the same time, this struggle for survival became the major concern of "southbound" (南來) right-wing intellectuals, who had recently begun settling in the British colony as a temporary refuge. They did not believe in the Communist vision for China, and took Hong Kong as a springboard to move farther away - toward Taiwan or Southeast Asia, or even farther, to the United States or the United Kingdom.

As the leftists went north, the southbound writers dominated the literary scene of 1950s Hong Kong. They had a few observable similarities: they were considered right-wing, in opposition to the communist left; they considered themselves temporary sojourners in Hong Kong; most of their literary activity was funded by the Asia Foundation (亞洲基金會), established by the United States Information Agency; and their cultural production was usually labeled "greenback culture" (綠背文化). Their journals, Everyman's Literature (人人文學) and Highland (海瀾), were exemplary of their literary 
production. One of the main editors of both of these journals, Li Kuang 力 匡, gained popularity early in the decade with a series of love poems in rhymed quatrains, written for a "short-haired and round-faced" girl back in Guangzhou. A typical poem, highlighting the formal elements of poetry, would be his “A Swallow's Words” (燕語). Its first stanza reads:

Now on your eaves, I must rest here,

Because the flight was long and weary.

"You are a stranger. Not from here!"

Ah, yes, I'm from a far-off country.

我此刻歇息在你底樑上，

爲了疲倦於長途的飛翔;

你說我像是個外地的客人,

是的我正來自遙遠的異鄉。

(Cheng 2013, 52)

The poetic form these right-wing poets chose was very close to the Crescent Society's (新月社) imitation of English Romantic poetry in 1920s Shanghai. Because of this influence, they have been labeled "Romantics" in studies of Hong Kong literature (Leung 1992, 224-227).

A dispute arose among the right-wing poets over emotion in Romantic poetry, and intriguingly ended with a split in their understanding of life. Among the writers associated with Everyman's Literature, Stephen Soong 宋淇 stood out as perhaps the most irascible, leaving him isolated as a translator. Although he wrote articles for Everyman's Literature introducing English poetry, Soong sharply indicted the poetics of English Romanticism as appropriated by Hong Kong's Romantics:

The function of emotion in poetry is esteemed as so high and important, it's as if without emotion, you can't have poetry, a view that follows the flourishing of Romanticism in the West in the $19^{\text {th }}$ century ... However the poetry of the moderns is a reaction against the poetry of the $19^{\text {th }}$ century ... For most modern poets, emotion is dispensable; emotion revealed in poetry is intolerably tacky.

(Soong 1982, 53)

Soong's critique was fiercely rejected by the Hong Kong Romantics. Chang Ting's 長亭 response links their preferred poetic form with their selfperception as “loyalists” (遺民): “The voice of the adherents of a lost nation 
is sad and thoughtful; poets in deep agony mourn their fate and reminisce about the past. This is our only hope of survival" (亡國之音哀以思，其民 困。困頓之民, 哀其所遇, 而追思往昔, 能有所追思, 則仍有一線希望 心之存在也) (Chang Ting 1982, 92-93). Eventually Soong proposed a truce in the debate, associating his distrust of sentimentalism in Hong Kong's Romantic poetry with a pioneering call for modernist poetics, citing Paul Valéry, Rainer Maria Rilke, and T. S. Eliot's use of understatement in "The Hollow Men" (Soong 1982, 97-99; for more, see Chan 2001, 85-93). Finally, Soong revealed:

Anti-communism is important, of course, but we cannot give up everyday life and the factors that maintain it ... On a spiritual level, we cannot give up literature or similar activities, because they nourish us, give us faith in life, keep us sympathetic to humanity.

(Soong 1982,3)

Reading the work of the writers and translators exiled to colonial Hong Kong in the 1950s (and that of those further excommunicated to Taiwan by the "bamboo curtain policy" [竹幕政策] of the Communist Party of China) calls for a sympathetic engagement with their modernist practice alongside their poor living conditions, harsh social milieu, and unenviable geopolitical environment. Once respectable men of letters in China in the 1940s, they were now doing menial jobs in Hong Kong, with some even writing pornography for newspaper supplements to be able to rent a single bunk for an entire family. Some took shelter in wooden sheds, which were vulnerable to typhoons and fires. It was under such humiliating conditions that the southbound writers continued to work to realize their lofty literary ideals, as though this writing was the last chance they had to continue both their spiritual and practical lives - that is, the last chance to hold on to life.

\section{The trope of life in Literary Currents}

Though their approaches were different, right-wing poets' writings and translations assembled a jigsaw puzzle of life in Hong Kong's literary landscape. But against Chang Ting's political sentiment that writing poetry to mourn and reminisce about the past was their "only hope of survival," and in contrast to Soong's apolitical counter-argument that everyday life is outside the political, Ronald Mar proposed a third poetics of life: modernism 
as constructed through the translation of Western poetry in his magazine Literary Currents (文藝新潮) (1956-1959).

Dissatisfied with the bifurcated literary scene in the 1950s, Mar decided to open up a new literary horizon by introducing Western modernism. Mar's bold manifesto called out to rally writers inspired by modernism, albeit with an image from Stalin: "Engineers of the human soul, rally to the flag!” 人類靈魂的工程師, 到我們的旗下來 (1956). This journal not only exerted influence on Hong Kong writers such as Quanan Shum 岑芘南, Wucius Wong 王無邪, and Wai-lim Yip 葉維廉, but also extended to the community of modernists in Taiwan, where it was circulated in the form of handwritten copies. Literary Currents is still considered one of the most important literary journals in the history of Hong Kong literature today.

In studying the poetry translations in Literary Currents, Yau Wai-ping 邱偉平 points out that the journal's advocacy for modernism “was neither a craze for a literary fad nor the pursuit of a new literary form, but came out of the need to borrow modernism to depict the complexity and conflict of modern life" (2013, 78). The trope of life in Literary Currents reveals a deep-seated link to a core concern of high modernism. According to Art Berman, high modernism, associated with the 1920 s of Eliot's The Waste Land and James Joyce's Ulysses, was "the most notable phase of modernism." High modernism is "not a style, a theme, a form, or a school," but rather an expression of a predominant attitude toward the function of literature in society: "[t]he writer undertakes a mission of utmost seriousness: to increase society's self-conscious realization of the unique dilemmas that had emerged as knowledge in every area had been called into question. Literature does not answer those questions; it provides a way of living among them" (1994, 60).

Of all the poetic techniques and thought that Mar and his followers borrowed from Western modernism, the most central component was to find a way to survive their hardships in Hong Kong at the spiritual level, through writing, translating, and commenting on literature. The emphasis on life and on survival sparks through the tireless expression of their aspiration for modernism. In his comment on American modernist poetry, Mar is full of praise:

After American poets turned to modernism, they unfettered themselves, widely using the living language, with fresh images and free forms ... breaking away from tradition, and enhancing expression in poetry ... They have used modern language and modern techniques to depict the most modern moods of Americans and the rhythms of modern life.

$(1956,2)$ 
In the introductory remarks on his translation of Stephen Spender's $195^{2}$ essay “The Modernist Movement is Dead," Yun Fu 雲夫 writes that for Spender,

art does not provide an escape for the artist or the appreciator, but contains "a true conflict in life." It dissects and dissolves all materials of life, emotions, and feelings, and expresses them.

$(1956,2)$

Elsewhere Li Wai-ling 李維陵 postulates that the “modern task” (現代任 務) of modernism is to

encourage man to search for the meaning of his and others' beings in the complex and rapidly changing modern life. This is to say that modern literary art should not only help modern man look courageously at modern life, but also to improve it with confidence.

$(1956,23)$

After all the modernist poetic techniques introduced through translation, after all the undecipherable image-heavy surrealist poems written in and translated into Chinese, and after all the modernist thought pitched to the polarized ideological environment in Hong Kong, eventually their modernist practice simply came down to the will to survive.

\section{The trope of life in Ronald Mar's translation and writing}

Scholarly attention to Mar's introduction of modernism to the conservative literary environment in 1950s Hong Kong has focused either on the poet's political stance or on his original writings (Leung 1982; Lok Fung 1990; Tang 1990; Leung 1992; Au 2010; Yip 2016). A close reading of Mar's translations against the trope of life, which he and his followers fiercely promoted, will crucially complement research to date and deepen our understanding of the inherent paradox that pervades modernism: that is, how the real finds poetic expression in the surreal.

Mar translated modernist poets from the US and the UK for two special features on Western modernist poetry in Literary Currents, and published translations of French surrealist poetry throughout the journal's lifetime, collaborating with various fellow translators. The feature on US poetry contains twenty-three poems by ten American modernists: Wallace Stevens 
(2), William Carlos Williams (3), Ezra Pound (4), Marianne Moore (1), T. S. Eliot (4), Archibald MacLeish (1), e. e. cummings (3), Hart Crane (1), Muriel Rukeyser (2), and Carl Shapiro (2). The feature on UK poetry contains twentyseven poems by ten British modernists: W. H. Auden (4), W. B. Yeats (3), D. H. Lawrence (3), Edith Sitwell (2), Cecil Day Lewis (2), Louis MacNeice (3), Stephen Spender (3), George Barker (2), David Gascoyne (2), and Dylan Thomas (3). ${ }^{2}$ Among the French poets Mar co-translated are Paul Valéry (1), Paul Fort (4), Guillaume Apollinaire (5), Max Jacob (3), Jules Supervielle (3), Remy de Gourmont (3), Paul Éluard (4), Henri Michaux (3), Jacques Prévert (1), René Char (1), André Breton (2), and Robert Desnos (2) - that is, thirty-two poems by twelve poets, mostly surrealists. Each of the three sets - US poetry, UK poetry, and French poetry - is considerably smaller in size than an average anthology in book form, but the selections unmistakably exhibit Mar's modernist aspirations. They constitute the first appearance of many of these poets in Chinese; certainly most of the individual poems had never been rendered into Chinese before. Mar exclusively chose those poets that come under high modernism.

The sense "that life must have an ultimate meaning, but one that can never be made fully explicit," Pericles Lewis explains, "pervades modernism." As a result, the modernists' "literary forms, rather than attempting to arrive at formal perfection, reflected the partial and fragmentary nature of their understanding of their culture" $(2007,120)$. This cultural crisis was perceived not only by high modernists, but also by modernists in Hong Kong like Yun Fu, Li Wai-ling, and Mar. Yau points out that Mar "emphasizes experiments with poetic language and opposes word games; accentuates that literature should face social reality and be tied closely to modern life" (2013, 75-84). This is reflected in his translations finding poetic expression in sudden and overwhelming revelations in the depiction of fragmented life. On this, Mar's 1956 translation of H.D.'s “Pear Tree” (梨樹) is exemplary:

Silver dust

lifted from the earth,

higher than my arms reach,

you have mounted.

O silver,

higher than my arms reach

you front us with great mass;
銀塵

從大地攀高,

高不可攀,

你升高了。

銀色啊,

高不可攀

你以大量迎向我們; 


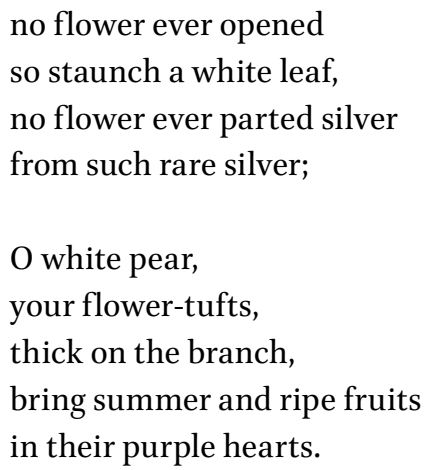

(H.D. 1988, 15-16)
沒有花開過

這樣白無點血的葉子,

沒有花從如此稀少的銀色裏

把銀色分開;

\author{
白梨啊, \\ 你的花簇 \\ 厚結在枝葉上， \\ 帶來夏天和成熟的果實 \\ 在他們紫色的心中。
}

(Mar 2014, 26)

Excusing the glaring mistake of translating the plant name "silver dust" (Jacobaea maritima) as 銀塵 (which literally means "silver dust"), when it should be 銀葉菊 (literally “silver-leaved chrysanthemum"), there is Mar's exceptional treatment of "staunch." As an adjective in H.D.'s line, it means loyal and committed, strong and firm; a straightforward corresponding Chinese translation could be jianzhen 堅貞. But in Mar's line it becomes the adjective baiwu dian xue 白無點血 'white without a stain of blood', which refers to the verb staunch, which means to stop the flow of blood from a wound. Thus, Mar uses a rhetorical device to translate this word: bai wu dian xue is anthimeric to "staunch." His translation rewrites but enriches H.D.'s largely concrete Imagist poem by creating not only the sharp contrast between white and red but also the dichotomy between white's presence and red's absence, between the real and the surreal. In so doing, paradoxically, the absence of the red evermore surrealistically reminds of the red (absence, as Joyce is supposed to have argued, is the highest form of presence). On the one hand, it hints at the speaker's contradictory feelings; on the other, it finds transient and powerful catharsis in this poetic expression, in this sole image from the outside world, in this single fragment of life.

Translations of Western modernist poetry introduced such complex expressions of the trope of life to the writers associated with Literary Currents. They found that the literary techniques employed in Western modernist poetry (which they translated, and rewrote) were embodiments of high modernism's literary aspirations, especially its concern with life at a philosophical level. In translating what they believed to be the most pioneering, often surrealist, poetry of Western modernism, they perceived a possibility of addressing their most real and practical concerns with survival - which was why they were so attracted to modernism in the first place, but this also indicates their poetics was encumbered from the 
beginning by the inherent dichotomy between the real and the surreal. Consequently, in the 1970s, this poetics lost much of its influence on the writing of poetry in Hong Kong, as I shall explain in the next section.

\section{The trope of life and the search for identity}

Literary Currents stopped publishing soon after Ronald Mar moved back to the US in 1958, but its efforts continued in various activities organized by the Association of Modern Literature and Art (現代文學美術協會), in the modernist literary magazines New Currents (新思潮) and Modern Edition (好望角), and in the “Repulse Bay” (淺水灣) supplement of the Hong Kong Times (香港時報), as well as in the Chinese Student Weekly (中國學生周報). All played major roles on the literary scene of Hong Kong in the 196os. The generation of Hong Kong writers who joined the local literary scene in the 1970 s had been nourished primarily on the modernist literature written and translated in the two postwar decades. Unlike the migrant writers in the 1950s, the baby boomers were not so critically concerned with survival in their philosophy of writing and translation, but felt the urge to search for an identity in their literature on the most visible level.

One of the key figures of this generation was Leung Ping-kwan, who revived the Poetry Page (詩之頁) of the Chinese Student Weekly in 1973 and became its last editor, until 1974. Leung described the excitement he had felt when he first encountered the modernist works published in Literary Currents:

Even with Hong Kong's reality as background, people were able to create pioneering works ... works stimulated by Hong Kong's unique time and space ... This taught me, then still searching, that little North Point, where we lived, could become the subject matter of literature.

(Leung 1982, 27)

The modernism promoted in Literary Currents inspired Leung not to adopt avant-garde Western poetics - certainly not the surrealistic poetry of Mar and his fellow author-translators - but simply to treat the place he lived as his subject matter. This inspiration was realized in Poetry Page's advocacy of what he called true-to-life poetry, which could be loosely defined as narrative poetry written in plain language with an emotionally reserved tone, most often set in Hong Kong or about Hong Kong (see Lo 2001 and Wong 2015). His poetry exudes a sense of place and of belonging. 
Thus, the trope of life in poetry was transformed and utilized by Leung and his followers as a means to search for identity in the couleur locale of the poetry they were writing. By advancing the idea of true-to-life, he resolved to distinguish the poetry of Hong Kong from both the poetry of mainland China, which he critiqued as too nationalistic and sentimental, and the poetry of Taiwan, which he believed was too idiosyncratically surrealistic (Leung 2007, 51). Although both were understood reductively in the 1970s, it was enough for Leung to find an opening through which he could define Hong Kong poetry for immediate identification by a local poetry readership and the budding poets associated with the Poetry Page. His efforts in constructing a subjectivity for Hong Kong poetry were further strengthened in the 1980 s by his and other Poetry Page authors' successful defense against the influence of Taiwanese poet Yu Kwang-chung's 余光 中 signature neoclassical style (see Wong 2016). Leung's curation of the above-mentioned monumental anthology Selected Poems of Ten Poets, published a year after the handover, reasserts the stylistic identity of Hong Kong poetry. It is no exaggeration to say that Leung started a true-to-life tradition of Hong Kong poetry in the 1970s and kept it alive for decades. Even after his passing in 2013, his tradition is carried on by middle-aged poets such as Chan Chi-tak 陳滅, Chow Hon-fai 周漢輝 - and, of course, by Chung Kwok-keung, who launched the attack on the surrealist poetry written by some of Hong Kong's youngest poets today.

\section{Conclusion: reading surrealist poetry in Hong Kong}

By reviewing the transformation of the trope of life since the 1950s, this paper offers a new angle on the interpretation of the dispute between the true-to-life school and the young surrealists in Hong Kong today. If the influence exerted by the 1950s translations of Western modernist poetry by Ronald Mar and others gradually decreased over the years, it was because the trope of life, so central to Mar and his followers' modernist practice, lost its historical burden of survival as the writers' core concerns evolved away from this, as a reflection of Hong Kong history. As southbound right-wing sojourners like Mar moved out or settled down more securely in the 1960s, they were followed by 1970 s authors such as Leung Ping-kwan, who had grown up in and with Hong Kong and felt an urgent need to seek a Hong Kong identity and distinguish their writing from that of other sinospheric areas. Leung rejected the surrealist quality of Mar's and his followers' translations and writings, presenting instead an entirely different understanding of life 
in developing a sense of belonging in his treatment of Hong Kong as subject matter per se. Thus, the trope of life transformed into what Leung called true-to-life poetry, by which he tried to protect what he perceived to be a Hong Kong subjectivity. Along these lines, the recent dispute between the true-to-life school and the young surrealists of Hong Kong's poetry scene can be understood as just another round of the former's defense against poetic influence from Taiwan.

The recent trend of surrealism in Hong Kong's poetry scene is, however, also reminiscent of the modernism of Mar and his circle in the 1950s. Despite a gap of half a century, there is an obvious stylistic affinity between the two, in that they both use surreal imagery as a medium to negotiate reality. Representative of Mar's poetry is “A Night in North Point” (北角之夜), a poem widely cited in studies of Hong Kong literature, which bears clear marks of surrealist influence in images such as, "Hence [I] fall into the drunkenness of amethyst” (於是陷入一種紫水晶裡的沉醉) and “creeks of mint wine" (薄荷酒的溪流), ${ }^{3}$ of which Chan Kwok-kuo has remarked that the "surreal allusions help create an effect where everything seems both real and illusory" $(2016,403)$. In theorizing the surreal quality of these young poets' imagery, Mu Yu 沐羽 (2015) and Huang Runyu 黃潤宇 (2015) argue that their imagery deliberately distances them from life to reflect critically upon the relationship between poetry and everyday reality. But compared to Mar and his followers' poetry and translations, the young surrealists' work lacks a genuine concern with life, with living, with survival at a philosophical level; compared to the true-to-life school advanced by Leung Ping-kwan, the young surrealists have yet to express the kind of alternative local subjectivity that could give the (Hong Kong) reader a sense of belonging. As this is an absence, or an incompleteness, that the true-to-life tradition cannot tolerate, their writings read as if written for the mere purpose of counter-attack, with their inspiration from Taiwanese poetry mentioned as a matter of expediency.

As these young poets continue to practice their surrealism, they may well take their poetry even further away from life. They seem to have chosen to ignore the reverberations of contemporary poetry outside the sinosphere. Only too soon have they suffered from the consequences inherent to surrealism, as J. P. Eburne warns, "abstracting its poetic devices and creative processes from ... political imperatives" $(2012,1377)$, not to mention, especially with an eye to their local situation, abstracting the surreal from the real, imagery from life. In other words, their transformation of the trope of life, 
first introduced by Mar and his followers, then tempered by Leung and fellow true-to-life authors, will only further disengage their poetry.

As for their proposal to incorporate surrealism into the true-to-life tradition, they have insufficiently theorized their poetic aspirations, and they have failed to introduce recent surrealist developments in contemporary world poetry - say, through translations of James Tate or John Ashbery - and an engagement with the postcolonial diasporic surrealism of Latin American poets such as Aldo Pellegrini, Braulio Arenas, and Enrique Molina. They even seem to have overlooked the bilingual volumes of Michael Palmer, Yves Bonnefoy, and Coral Bracho, published as part of the International Poets in Hong Kong series. Yet through translation, they could demonstrate, even renovate, their surrealism, just as Mar and his followers did vis-à-vis modernism in the 1950s, thereby bringing a new perspective to the trope of life in Hong Kong poetry. Perhaps only in this way could their surrealist poetry negotiate the current mainstream true-to-life tradition, and could they find a new definition of localness, a new sense of belonging, and a way back to the love of life in Hong Kong.

\section{Works cited}

Au Chung-to 區仲桃. 2010. 〈試論馬朗的現代主義〉 [On Ronald Mar's modernism]. 《文學評論》10,38-47.

Berman, Art. 1994. Preface to Modernism. Chicago: University of Illinois Press. Chan Chi-tak 陳智德. 2001.〈林以亮詩論與 50 年代香港新詩的轉變〉 [Stephen Soong's poetics and the transformation of Hong Kong poetry in the 1950s]. 《作家》11, 85-93.

Chan Kwok-kou. 2016. "Sense of Place and Urban Images: Reading Hong Kong in Hong Kong Poetry." In The Oxford Handbook of Modern Chinese Literature, edited by Carlos Rojas and Andrea Bachner, 399-416. New York: Oxford University Press. Chang Ting 長亭. 1982 [1953]. 〈詩和對詩的感應〉 [Poetry and sensibility]. In 《詩與情感》 [Poetry and emotion], edited by Stephen Soong, 91-93. Taipei: Dalin chubanshe.

Cheng Ching-hang 鄭政恆. 2013. 《五O香港詩選》 [An anthology of Hong Kong poetry of the 1950s]. Hong Kong: Chunghwa Books.

Chung Kwok-kueng 鍾國強. 2015. 〈本土詩的一種面向〉 [A facet of local poetry]. 《明月》11, 9-13.

Eburne, J. P. 2012. "Surrealism." In The Princeton Encyclopedia of Poetry and Poetics, 4th edition, edited by Roland Greene, 1377-1380. Princeton: Princeton University Press. 
H.D. 1988. Selected Poems, edited by Louis L. Martz. New York: New Directions. Huang Wanhua 黃萬華. 2013. 〈從《文潮》到《文藝新潮》: 一條不可忽視的文 學史綫索〉 [From Literary Wave to Literary Currents: an unignorable trace in literary history]. 《山東社會科學》9, 58-66.

Huang Runyu 黃潤宇. 2015. 〈本土詩及日常語言的畫外音〉 [The voice-over of local poetry and everyday language]. 《獨立媒體》. bit.ly/2I5x4Fn. Accessed April 1, 2018.

Lewis, Pericles. 2007. The Cambridge Introduction to Modernism. Cambridge: Cambridge University Press.

Leung Ping-kwan 梁秉鈞. 1971. 《美國地下文學選》 [An anthology of American underground literature] Taipei: Huanyu chubanshe.

-.1982. 〈從緬懷的聲音裡逐漸響現了現代的聲音〉 [Out of a nostalgic voice gradually emerges a modern voice]. 《素葉文學》5, 26-30.

- 1992. "Modern Hong Kong Poetry: Negotiation of Cultures and the Search for Identity." Modern Chinese Literature 9 (2), 221-245.

-.2007. 《僭越的夜行》 [Traversing the night], edited by Chan So-yee 陳素怡. Hong Kong: Wenhua gongfang, 2012.

Li Wai-ling 李維陵. 1956. 〈現代人·現代生活·現代文㙯〉 [Modern man, modern life, modern literature and art]. Literary Currents 《文藝新潮》 7, 21-27.

Lo Kwai-cheung 羅貴祥. 2001. 〈經驗與慨念的矛盾〉 [A conflict between experience and concept]. Hong Kong Literature as/and Cultural Studies 《香港文學@ 文化研究》, edited by Esther Mei-kwan Cheung 張美君 and Stephen Yiu-wai Chu 朱耀偉, 241-252. Hong Kong: Hong Kong University Press.

Lo Wai-luen 盧瑋鑾. 1996. 〈「南來作家」淺說〉 [On the southbound writers]. In Lo Wai-luen, 《香港故事》 [Hong Kong Stories], 118-128. Hong Kong: Oxford University Press.

Lok Fung 洛楓. 1990. 〈香港早期現代主義的發端〉 [The beginning of modernism in Hong Kong]. 《詩雙月刊》8, 30-35.

Mar, Ronald 馬朗. 1956. 〈人類靈魂的工程師, 到我們的旗下來!〉 [Engineers of the human soul, rally to the flag!]. Literary Currents 文藝新潮 1, 1-2.

一, ed. 1956. 〈英美現代詩專輯·美國部分〉 [Special features on British and American modern poetries, American section]. Literary Currents 文藝新潮 7, 47-63.

- 2003. 〈為什麼是現代主義? : 杜家祁、馬朗對談〉 [Why modernism?: a conversation between Du Jiaqi and Ronald Mar]. 《香港文學》224, 21-31.

—. 2014. 《變調: 馬博良譯詩集》 [Variations: collected poetry translations of Ronald Mar]. Macao: Association of Stories in Macao.

$\mathrm{MuYu}$ 沐羽. 2015. 〈本土詩歌風景〉 [A landscape of local poetry]. 《LA PETITE MORT》. bit.ly/2UCgNh7. Accessed September 1, 2018.

Qian Yating 錢雅婷, ed. 1998. 《十人詩選》 [Selected poems of ten poets]. Hong Kong: Qingwen shuwu. 
Soong, Stephen 宋淇. 1982. 《詩與情感》 [Poetry and emotion]. Taipei: Dalin chubanshe.

Song, Chris. 2017. "The Transculturation of American Poetry in China, 1917-1937." Journal of Modern Literature in Chinese 14 (2)-15 (1), 187-211.

Tang Zhenzhao 湯禎兆. 1990. 〈馬朗和《文藝新潮》的現代詩〉 [The modern poetry of Ronald Mar and Literary Currents]. 《詩雙月刊》6, 33-41.

Wong Ka-ki 王家琪. 2015. 〈抒情與寫實: 重釋也斯的「生活化」詩歌主張〉

[Lyricism and realism: re-interpreting Leung Ping-kwan's advocacy of true-to-life poetry]. 《中國現代文學》50, 129-148.

-.2016. 〈本土詩觀的角力史〉 [A history of the opposition of local poetics]. Fleurs des lettres 字花 59, 104-108.

Yau Wai-ping 邱偉平. 2013. 〈《文藝新潮》譯介現代主義詩作的選擇與取向〉

[A study of the translation of modernist poetry in Literary Currents]. Journal of Modern Chinese Literature 11 (1), 75-84.

Yip Wai-lim 葉維廉. 2016. 〈現代主義與香港現代詩的興發〉 [Modernism and the rise of modern poetry in Hong Kong]. 《晶石般的火焰》, vol. 1, 481-484. Taipei: National Taiwan University Press, 2016.

Yun Fu 雲夫, trans. 1956. Stephen Spender, 〈現代主義運動之消沉〉 [The modernist movement is dead] 《文㙯新潮》2, 2-5.

Zhang Songjian 張松建. 2009. 《現代詩的再出發》 [The re-emergence of modern poetry]. Beijing: Beijing daxue chubanshe.

\section{About the author}

Chris Song obtained his PhD in Translation Studies at Lingnan University. Since the early 2010 s he has been managing editor of the Journal of Modern Literature in Chinese and, from 2019, its successor Prism: Theory and Chinese Literature. His research interests include literary translation in the Chinese context, museum translation, and Hong Kong literature. A poet and translator of poetry, he has published five books of his own poetry and many volumes of poetry translation. He is editor-in-chief of the Hong Kong-based Chinese-English bilingual Voice \& Verse Poetry Magazine, and executive director of the International Poetry Nights in Hong Kong. 
